\title{
ISOLASI DAN IDENTIFIKASI BAKTERI PENGHASIL ALGINAT LYASE DARI RUMPUT LAUT Sargassum crassifolium
}

\section{Isolation and Identification Bacteria Producing Alginate Lyase Derived from Seaweed Sargassum crassifolium}

\author{
Subaryono ${ }^{1^{*}}$, Rosmawaty Peranginangin ${ }^{1}$, Maggy T. Suhartono ${ }^{2}$ dan Fransiska R. Zakaria ${ }^{2}$ \\ ${ }^{1}$ Balai Besar Penelitian dan Pengembangan Pengolahan Produk dan Bioteknologi Kelautan dan Perikanan, \\ JI. K.S. Tubun Petamburan VI, Jakarta Pusat, Indonesia \\ ${ }_{2}^{2}$ Fakultas Teknologi Pertanian IPB, Jl. Lingkar Akademik, Kampus IPB Darmaga, Bogor, Indonesia \\ * Korespondensi Penulis: yono_ipn@yahoo.co.id
}

Diterima: 20 Maret 2015; Disetujui: 24 Mei 2015

\begin{abstract}
ABSTRAK
Penelitian tentang isolasi dan identifikasi bakteri penghasil alginat lyase dari rumput laut coklat Sargassum crassifolium sudah dilakukan. Rumput laut didekomposisi selama 5 hari, dan bakteri dikultur dalam media luria bertani agar yang mengandung alginat $1 \mathrm{~g} / 100 \mathrm{ml}$. Setelah diinkubasi selama 3 hari, bakteri yang tumbuh diisolasi dan diseleksi untuk mendapatkan isolat yang positif menghasilkan alginat lyase. Aktivitas alginat lyase ditandai dengan adanya zona bening di sekitar koloni setelah ditetesi dengan larutan $10 \%$ setil piridinium klorida. Hasil penelitian menghasilkan 4 isolat bakteri dengan indeks alginolitik tertinggi yaitu S245, S235, S155, dan S215. Identifikasi ke-empat isolat dilakukan secara morfologi, biokimia, dan genetik. Pelitian menunjukkan bahwa isolat S245 memiliki kemiripan dengan Bacillus megaterium, S235 memiliki kemiripan dengan Bacillus thuringiensis, S155 memiliki kemiripan dengan Bacillus cereus, dan S215 memiliki kemiripan dengan Bacillus pseudomycoides.
\end{abstract}

KATA KUNCI: Sargassum crassifolium, alginat lyase, bakteri, rumput laut

\section{ABSTRACT}

Research to isolate and identify alginate lyase producing bacteria derived from seaweed Sargassum crassifolium had been carried out. The seaweed was decomposed for 5 days, and bacteria was cultured in luria bertani agar media containing alginate $1 \mathrm{~g} / 100 \mathrm{ml}$. After 3 days incubation period, cultured bacteria were isolated and screened to find the isolate that positive producing alginate lyase. Alginate lyase activity was shown by a clearing zone appears surround the bacterial colony, after poured with 10\% cetyl pyridinium cloride solution. The research found 4 isolat bacteria with higher alginolitic index which were S245, S235, S155 and S215. Identification of four isolate were conducted morphologically, biochemically and genetically. The research showed that isolate S245 was most identical to Bacillus megaterium, S235 identical to Bacillus thuringiensis, S155 identical to Bacillus cereus and S215 identical to Bacillus pseudomycoides.

KEYWORDS: Sarqassum crassifolium, alginate lyase, bacteria, seaweed

\section{PENDAHULUAN}

Alginat lyase merupakan salah satu enzim yang akhir-akhir ini banyak mendapat perhatian. Alginat lyase atau sering disebut alginase, merupakan enzim yang mengkatalisis pemecahan alginat dengan mekanisme eliminasi $\beta$ dari ikatan glikosil 4-O dan menghasilkan 4-deoxy-L-erythro-hex-4-ene piranosiluronat pada ujung gugus nonreduksi dari oligosakarida yang dihasilkan (Gacesa, 1992). Alginat lyase sudah banyak dilaporkan pemanfaatannya seperti dalam produksi oligosakarida bioaktif, pengaturan sifat rheologi polisakarida, dan analisis struktur polisakarida (Subaryono et al., 2013). Produk hasil pemecahan alginat lyase yang dikenal sebagai alginate oligosaccharides (AOS) dilaporkan memiliki berbagai aktivitas biologi seperti sebagai probiotik, pengaturan sistem kekebalan tubuh, antikoagulasi, antioksidan, anti kanker, aktivitas pemacu pertumbuhan, pemacu produksi antibiotik dan pemacu produksi ethanol (Gibson \& Roberfroid, 1995; Iwamoto et al., 2005; Guo, et al., 2011; Khan et al., 2011). 
Bakteri penghasil alginat lyase berhasil diisolasi dari berbagai sumber seperti bakteri tanah, bakteri laut, moluska dan krustasea laut, alga coklat, dan jamur (Wong et al., 2000). Bakteri alginolitik penghasil alginat lyse yang berasal dari tanah maupun laut dan sudah diisolasi antara lain Bacillus sp. ATB-1015 (Nakagawa et al., 1998), Pseudomonas sp. QD03 (Xiao et al., 2006), Pseudoalteromonas atlantica AR06 (Matsushima et al., 2010), Pseudoalteromonas sp. SM0524 (Li et al., 2011a), Pseudomonas fluorescens HZJ216 (Li et al., 2011b), Flavobacterium sp. S20 (Lishuxin et al., 2013) dan Stenotrophomas maltophilia KJ-2 (Lee et al., 2012).

Sebagai negara yang berada di daerah tropis dan kaya akan biodiversitas makhluk hidup, maka potensi untuk mendapatkan alginat lyase baru dari Indonesia masih sangat besar. Indonesia kaya akan rumput laut penghasil alginat seperti Sargassum sp. dan Turbinaria sp., sehingga keberadaan bakteri yang mampu mendekomposisi rumput laut tersebut diduga menghasilkan alginat lyase. Meskipun demikian, isolasi bakteri penghasil alginat lyase dari Indonesia belum banyak dilaporkan. Dalam penelitian ini dilakukan isolasi dan identifikasi bakteri penghasil alginat lyase dari rumput laut Sargassum crassifolium yang telah dibusukkan terlebih dahulu, mengingat rumput laut ini merupakan jenis penghasil alginat yang potensial di Indonesia.

\section{BAHAN DAN METODE}

\section{Bahan Baku}

Bahan baku rumput laut Sargassum crassifolium diperoleh dari perairan Binuangeun, Provinsi Banten. Media pertumbuhan bakteri seperti pepton, ekstrak khamir dan agar diperoleh dari Oxoid, Co Ltd. Bahan kimia untuk pengujian aktivitas enzim seperti $\mathrm{NaOH}$, natrium bisulfit, kalium-natrium tartrat dan fenol diperoleh dari Merck Co Ltd. Manosa dan Dinitro salycil acid (DNS) diperoleh dari Sigma Co Ltd.

\section{Isolasi Bakteri Penghasil Alginat Lyase}

Rumput laut dibusukkan di dalam erlenmeyer tertutup pada suhu kamar selama 5 hari. Selanjutnya bakteri ditumbuhkan di dalam media luria bertani agar yang mengandung alginat $1 \mathrm{~g} / 100 \mathrm{ml}$ dan diinkubasi selama 3 hari pada suhu $30^{\circ} \mathrm{C}$. Koloni bakteri yang tumbuh dan menunjukkan karakteristik morfologi koloni yang berbeda selanjutnya diisolasi kembali dan ditumbuhkan secara terpisah dalam media yang sama. Untuk melihat adanya aktivitas alginat lyase secara kualitatif, dituangkan larutan 10\% setil piridinium klorida ke sekeliling koloni bakteri dan dibiarkan 30 menit pada suhu ruang. Terbentuknya zona bening di sekeliling bakteri menunjukkan adanya aktivitas alginat lyase. Diameter zona bening dan diameter koloni diukur, dan aktivitas alginat lyase dinyatakan sebagai indeks alginolitik yang merupakan perbandingan diameter zona bening dibagi dengan diameter koloni bakteri.

\section{Identifikasi Bakteri}

Identifikasi bakteri dilakukan terhadap empat bakteri yang memiliki indeks alginolitik tertinggi. Identifikasi bakteri dilakukan dengan pengamatan secara morfologi, biokimia dan genetik. Pengamatan secara morfologi terhadap koloni bakteri yang tumbuh pada media agar dilakukan di bawah mikroskop setelah pengecatan Gram dan spora. Identifikasi secara biokimia dilakukan dengan melihat kemampuan bakteri memetabolisme berbagai jenis gula dengan bantuan API bacterial kit identification pada isolat bakteri dengan umur 24 jam. Selanjutnya untuk melihat jenis bakteri data tersebut diolah dengan bantuan software ABIS online. Identifikasi secara genetik dilakukan dengan uji sequencing 16S rDNA. Ekstraksi DNA dilakukan dengan DNA Purification Kit (Fermentas Life Bioscience, EU) terhadap isolat bakteri yang sudah berumur 24 jam. Primer yang digunakan untuk amplifikasi 16S rDNA adalah fragment $63 f$ (5'-CAGGCCTAACACAGGCAAGTC) dan 1387r (5'GGGCGGWGTGTACAAGGC). Pemilihan kedua jenis primer ini karena merupakan primer umum yang sering digunakan untuk identifikasi bakteri penghasil alginat lyase, sehingga peluang memiliki kecocokan dengan pita DNA berbagai jenis bakteri yang diuji cukup besar. PCR dilakukan dengan GeneAmp PCR System 9700 (Applied Biosystem, Foster City, CA, USA) dengan kondisi amplifikasi: initial denaturation pada $95{ }^{\circ} \mathrm{C}$ selama 5 menit, denaturation pada $95^{\circ} \mathrm{C}$ selama 1 menit, annealing pada $56^{\circ} \mathrm{C}$, dan extension pada $72^{\circ} \mathrm{C}$ selama 1,5 menit, dan final extension pada $72^{\circ} \mathrm{C}$ selama 7 min. Sequence $16 \mathrm{~S}$ rDNA kemudian dibandingkan dengan multiple sequence data pada GenBank database dengan BLAST algorithm dan program CLUSTAL W. dan kemudian dibuat pohon filogenetik yang diperoleh dari program tersebut.

\section{HASIL DAN BAHASAN}

\section{Karakteristik Isolat Bakteri yang Positif Memproduksi Alginat Lyase}

Dari 10 (sepuluh) isolat bakteri yang diperoleh, 8 (delapan) di antaranya positif yang ditunjukkan oleh adanya zona bening di sekeliling koloni setelah 
ditetesi larutan 10\% setil piridinium klorida atau teridentifikasi sebagai bakteri yang positif menghasilkan alginat lyase. Ke delapan isolat tersebut menunjukkan karakteristik koloni seperti pada Tabel 1. Dari tabel tersebut, terlihat bahwa nilai indek alginolitik isolat bakteri yang diperoleh pada isolasi ini berkisar antara 1,14 $\pm 0,03$ sampai dengan 3,78 \pm 0,09 . Empat isolat dari ke-delapan isolat yang positif meghasilkan alginat lyase ini memiliki nilai indek alginolitik yang cukup besar (indek alginolitik > 2), sedang empat isolat lainnya memiliki indeks alginolitik yang kecil. Ke empat isolat yang memiliki indek alginolitik terbesar tersebut berturut-turut adalah isolat S245 dengan indek alginolitik sebesar 3,78 $\pm 0,09$ diikuti isolat S235 dengan indek alginolitik $3,42 \pm 0,48$, isolat S155 dengan indek alginolitik 3,09 $\pm 0,37$ dan isolat S215 dengan indek alginolitik 2,85 $\pm 0,19$. Indek alginolitik ini dapat digunakan untuk memprediksi aktifitas alginat lyase atau jumlah enzim yang diproduksi oleh bakteri tersebut. Semakin besar nilai indek alginolitik menunjukkan aktivitas alginat lyase atau jumlah enzim yang diproduksi yang lebih besar. Beberapa penelitian sebelumnya juga menggunakan metode ini untuk menseleksi bakteri yang memiliki

Tabel 1. Karakteristik koloni bakteri yang positif menghasilkan alginat lyase

Table 1. Characteristic of colony bacteria that positive producing alginate lyase

\begin{tabular}{|c|c|c|c|}
\hline No & $\begin{array}{l}\text { Isolat Bakteril } \\
\text { Bacteria Isolate }\end{array}$ & Karakteristik/Characteristics & $\begin{array}{l}\text { Indeks Alginolitik*I } \\
\text { Alginolitic Index }\end{array}$ \\
\hline 1 & S113 & $\begin{array}{l}\text { Warna koloni orange kekuningan, permukaan halus } \\
\text { dan sedikit transparan atau mengkilat/Colony is } \\
\text { yellowish orange, smooth surface and slightly } \\
\text { transparent or shine }\end{array}$ & $1.14 \pm 0.03$ \\
\hline 2 & S123 & $\begin{array}{l}\text { Warna koloni putih susu, bagian pinggir koloni tidak } \\
\text { halus dengan ukuran besar atau melebar/Colony is } \\
\text { milky white, edge of colony not smooth, with bigger } \\
\text { colony size or widerspread }\end{array}$ & $1.18 \pm 0.04$ \\
\hline 3 & $\mathrm{~S} 133$ & $\begin{array}{l}\text { Warna koloni putih susu, pinggir koloni halus, } \\
\text { transparan atau mengkilat/Colony is milky white, } \\
\text { edge of colony smooth, transparent or shine }\end{array}$ & $1.29 \pm 0.08$ \\
\hline 4 & S155 & $\begin{array}{l}\text { Warna koloni putih susu, pinggir koloni halus, tidak } \\
\text { mengkilat/Colony is milky white, side of colony } \\
\text { smooth, not shiny }\end{array}$ & $3.09 \pm 0.37$ \\
\hline 5 & S215 & $\begin{array}{l}\text { Koloni bulat dengan pinggiran kekuningan dan } \\
\text { bagian tengah krem, permukaan koloni tidak } \\
\text { halus/Rounded colony with yellowish edge and } \\
\text { cream-colored in the middle, the surface of colony } \\
\text { unsmooth }\end{array}$ & $2.85 \pm 0.19$ \\
\hline 6 & S225 & $\begin{array}{l}\text { Koloni bulat, warna kuning gelap, permukaan koloni } \\
\text { halus, agak transparan/Rounded colony with dark } \\
\text { yellowish color, smooth surface slightly transparent }\end{array}$ & $1.28 \pm 0.05$ \\
\hline 7 & S235 & $\begin{array}{l}\text { Koloni bagian tengah berwarna krem dengan pinggir } \\
\text { transparan/Cream-colored colonies in the middle } \\
\text { with transparent edges }\end{array}$ & $3.42 \pm 0.48$ \\
\hline 8 & S245 & $\begin{array}{l}\text { Warna koloni coklat muda dengan permukaan bintil- } \\
\text { bintil/Russet colony, with nodule on the surface }\end{array}$ & $3.78 \pm 0.09$ \\
\hline
\end{tabular}

* Nilai merupakan rerata dari tiga kali ulangan dengan standar deviasinya/The value was average of three replicates with its standard deviation 
aktivitas alginat lyase, meskipun tidak melaporkan nilai indeks alginolitiknya (Kawamoto et al., 2006; Kim et al., 2009).

\section{Identifikasi Isolat Bakteri Penghasil Alginat Lyase}

Hasil pengamatan morfologi bakteri penghasil alginat lyase di bawah mikroskop setelah pengecatan Gram ditampilkan pada Gambar 1. Ke empat bakteri penghasil alginat lyase ini merupakan kelompok bakteri Gram positif, berbentuk batang (basil), dan penghasil spora. Isolat S245 berbentuk batang dengan ukuran cukup besar tetapi pendek-pendek, dan menghasilkan spora di bagian tengah bakteri. Isolat S235 juga berbentuk batang tetapi dengan ukuran yang lebih besar dan lebih panjang serta cenderung berbentuk rantai. Sementara itu isolat S155 memiliki ukuran yang mirip dengan S245 tetapi sedikit lebih panjang. Isolat S215 memiliki bentuk yang paling ramping tetapi dengan ukuran yang lebih panjang atau hampir sama dengan isolat S235. Bakteri ini menghasilkan spora yang terletak di bagian sentral atau para-sentral (gambar tidak diperlihatkan).

Hasil identifikasi secara biokimia dengan API bacterial kit identification ditampilkan pada Tabel 2. Terlihat bahwa ke empat isolat adalah Gram, katalase dan oxidase positif, tetapi memiliki perbedaan dalam memetabolisme berbagai jenis gula yang diujikan. Hasil pengolahan data dengan bantuan software $A B I S$ online untuk identifikasi jenis bakteri ini ditampilkan pada Tabel 3. Dari tabel terlihat bahwa Isolat S245 memiliki kemiripan dengan Bacillus megaterium 85\%, Paenibacillus macerans 78\%, Bacillus amyloluquifaciens 78\% dan Bacillus subtilis 76\%. Isolat S235 memiliki kemiripan dengan Bacillus thuringiensis $86 \%$, Bacillus cereus $82 \%$, Bacillus anthracis $76 \%$ dan Bacillus mycoides $71 \%$. Sementara itu isolat S155 memiliki kemiripan dengan Bacillus cereus $90 \%$, Bacillus thuringiensis $86 \%$, Bacillus mycoides $82 \%$ dan Bacillus anthracis $81 \%$. Isolat S215 memiliki kemiripan dengan Bacillus mycoides ID 92\%, Bacillus cereus ID 86\%, Bacillus anthracis ID 82\%, dan Bacillus thuringiensis ID 82\%.
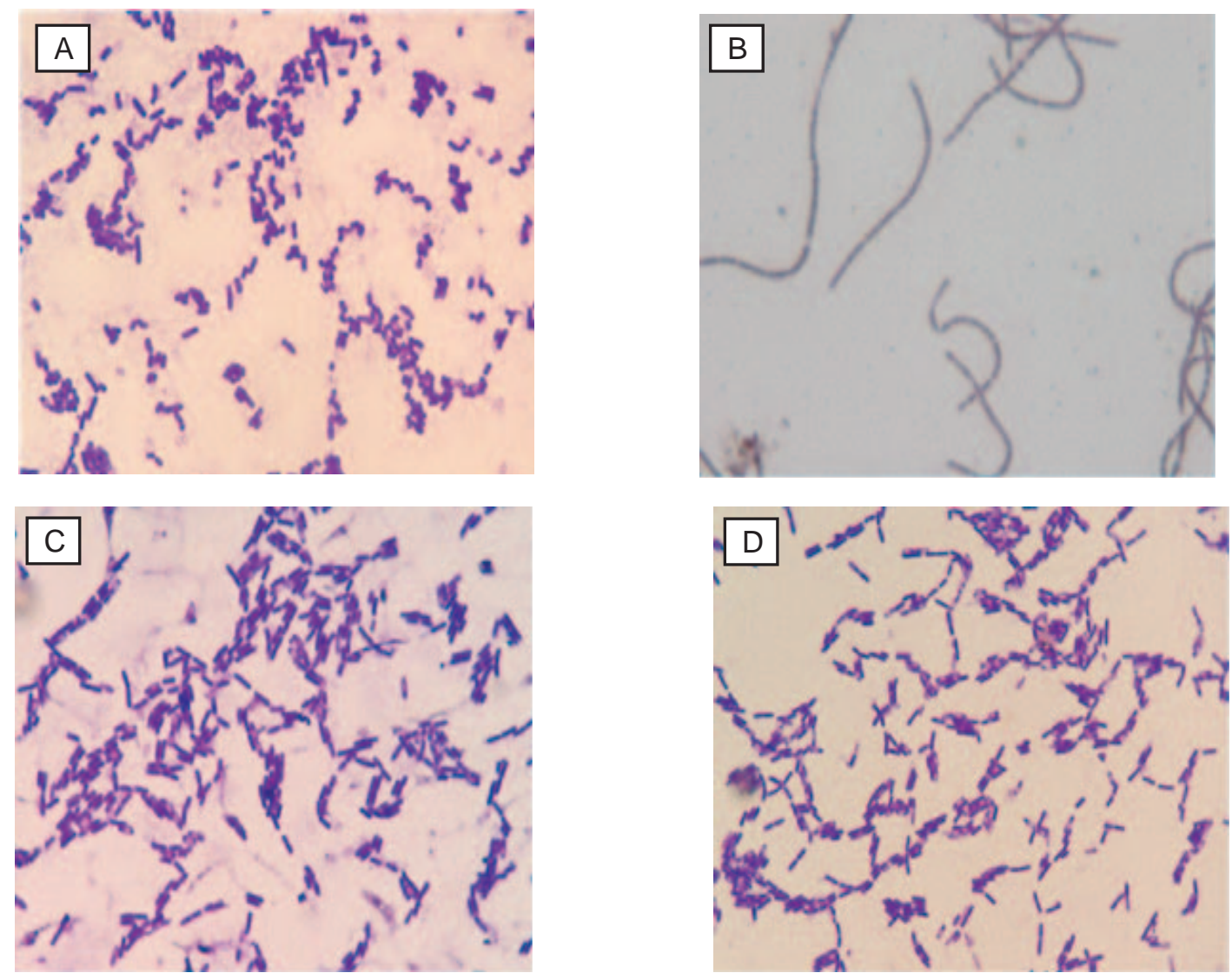

Gambar 1. Foto isolat bakteri di bawah mikroskop setelah pengecatan gram (perbesaran $1000 \mathrm{x}$ ). A:S245, B: S235, C:S155, D: S215.

Figure 1. Photograph of isolate bacteria under microscope after gram staining (magnificent $1000 \times$ ) A: S245, B: S235, C:S155, D: S215. 
Tabel 2. Hasil uji biokimia bakteri penghasil alginat dengan API bacterial kit identification

Table 2. Biochemical test result of bacteria producing alginate lyase with API bacterial kit identification

\begin{tabular}{lcccc}
\hline Isolat/lsolate & S245 & S235 & S155 & S215 \\
\hline Gram & + & + & + & + \\
katalase & + & + & + & + \\
oksidase & + & + & + & + \\
ADH & - & + & - & - \\
LDC & - & + & - & - \\
ODC & - & - & - & - \\
CIT & - & + & + & - \\
H2S & - & - & - & - \\
URE & - & - & - & - \\
TDA & - & - & - & - \\
IND & - & - & - & - \\
VP & - & - & + & + \\
GEL & + & + & + & + \\
GLU & + & + & - & - \\
MAN & - & + & - & - \\
INO & - & - & + & - \\
SOR & - & - & - & - \\
RHA & - & - & + & - \\
SAC & + & - & - & - \\
MEL & + & - & - & - \\
AMY & + & + & - & - \\
ARA & - & - & - & - \\
\hline
\end{tabular}

Berdasar perbedaan sifat biokimianya, bakteri dapat diidentifikasi dengan cara membandingkan hasil pengujian dengan data base yang terdapat pada soft ware. Meskipun demikian data base yang sudah tersedia pada soft ware tersebut belum mencakup semua jenis bakteria sehingga hasil pengujian akan ditunjukkan dengan berapa kemiripan dengan data base yang sudah tersedia. Semakin dekat kemiripan suatu bakteria dengan data base tersebut maka kemungkinan bakteri ini berasal dari genus atau jenis yang sama semakin besar. Bossard et al. (2006) menyatakan bahwa salah satu kelemahan identifikasi bakteri secara fenotip seperti dengan API test kit ini adalah keterbatasan data base yang dimiliki dibandingkan data base yang terdapat pada sistem identifikasi secara genetik.

Hasil uji biokimia menunjukkan bahwa keempat bakteri ini memiliki sifat yang sama yaitu Gram positif, katalase positif dan oksidase positif. Kebanyakan bakteri Gram positif bersifat tidak patogen, sedangkan 90-95\% bakteri Gram negatif bersifat patogen bagi manusia (Anon., 2015). Dengan demikian maka sifat
Gram positif ini mengindikasikan lebih aman karena selain kebanyakan bersifat tidak patogen, bakteri Gram positif ini umumnya bersifat tidak resisten antibiotik seperti halnya bakteri gram negatif. Dengan demikian maka penanganan infeksi jenis bakteri ini umumnya lebih mudah dilakukan. Adanya sifat katalase positif menunjukkan bahwa keempat bakteri ini memiliki enzim katalase yang dapat memecah $\mathrm{H}_{2} \mathrm{O}_{2}$ menjadi $\mathrm{H}_{2} \mathrm{O}$ dan $\mathrm{O}_{2}$, atau bakteri ini dapat hidup pada suasana aerob. Oksidase positif dari bakteri-bakteri ini menunjukkan bahwa bakteri ini memiliki enzim sitokrom oksidase yang merupakan ciri bakteri aerob atau fakultatif anaerob (Trivedi et al., 2010). Dari kemampuannya memetabolisme gula, terlihat bahwa beberapa bakteri ini mampu memanfaatkan glukosa, manosa, inositol, rhamnosa, sakarosa maupun melobiose sebagai sumber karbonnya. Hal ini menunjukkan bahwa meskipun bakteri ini penghasil alginat lyase, tetapi sumber karbonnya tidak hanya semata-mata dari kemampuannya mendegradasi alginat tetapi juga dapat memanfaatkan beberapa sumber karbohidrat lain. 
Tabel 3. Hasil identifikasi bakteri penghasil alginat lyase dengan bantuan sofware ABIS online Table 3. Identification result of alginate lyase producing bacteria with sofware ABIS online

\begin{tabular}{lll}
\hline \multirow{2}{*}{ Isolat/Isolate } & Jenis Bakteri/Bacteria Species & Kemiripan IID \\
\hline S245 & Bacillus megaterium & $85 \%$ \\
& Paenibacillus macerans & $78 \%$ \\
& Bacillus amyloliquifaciens & $78 \%$ \\
& Bacillus subtilis & $76 \%$ \\
\hline S235 & Bacillus thuringiensis & $86 \%$ \\
& Bacillus cereus & $82 \%$ \\
& Bacillus anthracis & $76 \%$ \\
& Bacillus mycoides & $71 \%$ \\
\hline S155 & Bacillus cereus & $90 \%$ \\
& Bacillus thuringiensis & $86 \%$ \\
& Bacillus mycoides & $82 \%$ \\
& Bacillus anthracis & $81 \%$ \\
\hline S215 & Bacillus mycoides & $92 \%$ \\
& Bacillus cereus & $86 \%$ \\
& Bacillus anthracis & $82 \%$ \\
& Bacillus thuringiensis & $82 \%$ \\
\hline
\end{tabular}

Hasil PCR (polymerase chain reaction) bakteri menunjukkan bahwa gen penyandi $16 \mathrm{~S}$ rDNA ini memiliki 1500 pasang basa (Gambar tidak ditampilkan). Hasil identifikasi secara genetik dengan uji sequencing $16 \mathrm{~S}$ rDNA disajikan pada Tabel 4. Secara umum hasil identifikasi dengan sequencing 16S rDNA ini memiliki kemiripan yang lebih tinggi jika dibandingkan secara biokimia. Hal ini kemungkinan disebabkan karena dengan metode biokimia (fenotipik) lebih banyak faktor yang mempengaruhi hasil identifikasi seperti kondisi isolat, umur isolat, kondisi lingkungan maupun faktor lain yang menyebabkan kemampuan metabolisme bakteri terganggu. Seperti diketahui bahwa identifikasi secara biokimia didasarkan pada kemampuan bakteri memetabolisme berbagai bahan yang diujikan. Meskipun demikian hasil identifikasi dengan sequencing $16 \mathrm{~S}$ rDNA ini sering memperoleh nilai kemiripan yang sama untuk beberapa spesies sekaligus. Hal ini tentunya menyulitkan untuk menentukan spesies mana sebenarnya isolat yang sedang diuji, sehingga kombinasi dengan uji secara biokimia sangat membantu meyakinkan spesies yang sedang diuji. Beberapa hasil penelitian sebelumnya juga menunjukkan bahwa identifikasi dengan sequencing $16 \mathrm{~S}$ rDNA ini sering menghasilkan kemiripan yang tinggi khususnya untuk spesies bakteri yang masih dalam satu kerabat karena adanya kemiripan sequen 16S rDNA nya (Bosshard, 2006).
Oleh karenanya identifikasi dengan metode ini sering memerlukan klarifikasi secara biokimia atau untuk meningkatkan spesifisitas terhadap bakteri yang diujikan maka digunakan marker yang spesifik untuk spesies tersebut.

Berdasar hasil tersebut maka diketahui bahwa isolat S245 paling mirip dengan Bacillus megaterium dengan ID 96\%. Hal ini sesuai dengan identifikasi secara biokimia yang menunjukkan bahwa bakteri ini juga paling mirip dengan Bacillus megaterium dengan ID $85 \%$, sehingga kemungkinan besar bakteri ini adalah Bacillus megaterium. Isolat S235 memiliki kemiripan dengan Bacillus thuringiensis, Bacillus anthracis str. Sterne, Bacillus anthracis str. Ames, Bacillus toyonensis BCT-7112, Bacillus cereus ATCC 14579, Bacillus pseudomycoides DSM 12442, Bacillus weihenstephanensis KBAB4 masing-masing dengan ID 99\%, kemiripan dengan Bacillus cytotoxicus NVH 391-98 ID 98\%, dan dengan Bacillus megaterium DSM 319 ID 96\%. Jika dibandingkan dengan uji biokimia, maka isolat ini teridentikasi sebagai Bacillus thuringiensis ID 86\%. Oleh karena itu disimpulkan bahwa isolat S235 ini adalah dari jenis Bacillus thuringiensis. Isolat S155 memiliki kemiripan dengan Bacillus thuringiensis, Bacillus anthracis str. Sterne, Bacillus anthracis str. Ames, dan Bacillus cereus ATCC 14579 dengan ID masing-masing 98\%, serta kemiripan dengan Bacillus toyonensis BCT-7112 ID 97\%. Secara bioimia, isolat S155 ini memiliki kemiripan dengan 
Bacillus cereus ID 90\%, sehingga kemungkinan besar isolat ini adalah dari jenis Bacillus cereus. Sementara itu isolat S215 memiliki kemiripan dengan Bacillus thuringiensis, Bacillus anthracis str. Sterne, Bacillus anthracis str. Ames, Bacillus cereus ATCC 14579, Bacillus pseudomycoides DSM 12442 dan Bacillus toyonensis BCT-7112 masing-masing dengan ID 98\% dan kemiripan dengan Bacillus weihenstephanensis KBAB4 ID 87\%. Secara biokimia, isolat S215 ini memiliki kemiripan dengan Bacillus mycoides ID 92\%, sehingga kemungkinan besar isolat ini dari jenis Bacillus pseudomycoides atau Bacillus mycoides. Semua isolat yang diuji dengan sequen $16 \mathrm{~S}$ rDNA tidak ada yang memiliki homologi $100 \%$, sehingga dapat disimpulkan bahwa spesies ini merupakan galur baru dari spesies yang sudah teridentifikasi sebelumnya dan tersimpan datanya dalam Genbank.

Keberadaan bakteri dari genus bacillus dalam rumput laut Sargassum crassifolium ini kemungkinan besar disebabkan karena kesamaan kondisi

Tabel 4. Hasil identifikasi bakteri penghasil alginat lyase dengan uji sequensing 16S rDNA

Table 4. Identification result of bacteria producing alginate lyase using $16 S$ rDNA sequencing

\begin{tabular}{|c|c|c|}
\hline Isolat/Isolate & Jenis Bakteri/Bacteria Species & Kemiripan/ID \\
\hline \multirow[t]{5}{*}{ S245 } & Bacillus megaterium DSM 319 chromosome, complete genome & $96 \%$ \\
\hline & Bacillus sp. 1NLA3E, complete genome & $94 \%$ \\
\hline & Bacillus infantis NRRL B-14911, complete genome & $94 \%$ \\
\hline & $\begin{array}{l}\text { Bacillus pseudomycoides DSM } 12442 \text { chromosome, whole genome } \\
\text { shotgun sequence }\end{array}$ & $93 \%$ \\
\hline & Bacillus weihenstephanensis KBAB4 chromosome, complete genome & $93 \%$ \\
\hline \multirow[t]{9}{*}{ S235 } & $\begin{array}{l}\text { Bacillus thuringiensis serovar konkukian str. 97-27 chromosome, } \\
\text { complete genome }\end{array}$ & $99 \%$ \\
\hline & Bacillus anthracis str. Sterne chromosome, complete genome & $99 \%$ \\
\hline & Bacillus anthracis str. Ames chromosome, complete genome & $99 \%$ \\
\hline & Bacillus toyonensis BCT-7112, complete genome & $99 \%$ \\
\hline & Bacillus cereus ATCC 14579 chromosome, complete genome & $99 \%$ \\
\hline & $\begin{array}{l}\text { Bacillus pseudomycoides DSM } 12442 \text { chromosome, whole genome } \\
\text { shotgun sequence }\end{array}$ & $99 \%$ \\
\hline & Bacillus weihenstephanensis KBAB4 chromosome, complete genome & $99 \%$ \\
\hline & Bacillus cytotoxicus NVH 391-98 chromosome, complete genome & $98 \%$ \\
\hline & Bacillus megaterium DSM 319 chromosome, complete genome & $96 \%$ \\
\hline \multirow[t]{5}{*}{ S155 } & $\begin{array}{l}\text { Bacillus thuringiensis serovar konkukian str. 97-27 chromosome, } \\
\text { complete genome }\end{array}$ & $98 \%$ \\
\hline & Bacillus anthracis str. Sterne chromosome, complete genome & $98 \%$ \\
\hline & Bacillus anthracis str. Ames chromosome, complete genome & $98 \%$ \\
\hline & Bacillus cereus ATCC 14579 chromosome, complete genome & $98 \%$ \\
\hline & Bacillus toyonensis BCT-7112, complete genome & $97 \%$ \\
\hline \multirow[t]{7}{*}{ S215 } & $\begin{array}{l}\text { Bacillus thuringiensis serovar konkukian str. 97-27 chromosome, } \\
\text { complete genome }\end{array}$ & $98 \%$ \\
\hline & Bacillus anthracis str. Sterne chromosome, complete genome & $98 \%$ \\
\hline & Bacillus anthracis str. Ames chromosome, complete genome & $98 \%$ \\
\hline & Bacillus cereus ATCC 14579 chromosome, complete genome & $98 \%$ \\
\hline & $\begin{array}{l}\text { Bacillus pseudomycoides DSM } 12442 \text { chromosome, whole genome } \\
\text { shotgun sequence }\end{array}$ & $98 \%$ \\
\hline & Bacillus toyonensis BCT-7112, complete genome & $98 \%$ \\
\hline & Bacillus weihenstephanensis KBAB4 chromosome, complete genome & $97 \%$ \\
\hline
\end{tabular}


lingkungan tempat rumput laut tersebut tumbuh yaitu di laut dan dalam kondisi aerob serta tersedianya komponen nutrisi yang memungkinkan bagi berkembangnya jenis bakteri ini. Kondisi perairan yang kaya akan garam tidak menghalangi jenis-jenis bakteri ini untuk tumbuh mengingat sifat Bacillus megaterium, Bacillus cereus, Bacillus thuringiensis dan Bacillus pseudomycoides yang umumnya masih dapat bertahan dalam lingkungan dengan kandungan $\mathrm{NaCl}$ 2-7\% (Todar, 2015). Bahkan ada satu jenis Bacillus megaterium yang mampu bertahan pada kadar $\mathrm{NaCl}$ 15\% (Khan, 2011). Kondisi perairan yang memiliki gelombang yang cukup besar menyebabkan besarnya agitasi yang merupakan sumber difusi oksigen ke dalam air laut.

Bakteri hidup menempel dan berasosiasi dengan rumput laut seringkali disebabkan karena adanya simbiosis yang saling menguntungkan antara keduanya. Beberapa alga memerlukan vitamin tertentu yang dalam beberapa hal sering disuplai oleh bakteri yang tumbuh menempel pada rumput laut tersebut. Sebaliknya, bakteri ini dengan kemampuannya memproduksi enzim tertentu memungkinkan untuk memanfaatkan komponen-komponen seluler dari alga tempatnya menempel. Oleh karenanya beberapa species bakteri menunjukkan adanya spesifitas inang, karena komponen yang terkandung pada satu inang akan berbeda dengan inang yang lain (Villareal-Gomez et al., 2010). Dikaitkan dengan hasil penelitian ini, diduga kandungan alginat dalam rumput laut Sargassum crassifolium ini dapat dimanfaatkan sebagai sumber karbon oleh jenis-jenis bakteri dari kelompok Bacillus yang memiliki aktifitas alginat lyase. Selain itu antar mikroorganisme yang menempel pada satu inang yang sama sering kali memiliki sifat antagonistik spesifik antara satu dengan lainnya (Villareal-Gomez et al., 2010). Dalam penelitian ini terlihat bahwa jenis-jenis bakteri yang berhasil diisolasi dari rumput laut ini adalah dari genus Bacillus, yang diduga mempunyai sifat antagonistik dengan bakteribakteri dari genus lainnya tetapi tidak antar mereka sendiri.

\section{KESIMPULAN}

Dari penelitian ini dapat disimpulkan bahwa bakteri penghasil alginat lyase berhasil diisolasi dari rumput laut Sargassum crassifolium yang sudah terdekomposisi. Bakteri yang memiliki nilai indeks alginolitik tinggi adalah isolat S245 yang teridentifikasi sebagai Bacillus megaterium, isolat S235 yang teridentifikasi sebagai Bacillus thuringiensis, isolat S155 yang teridentifikasi Bacillus cereus, dan isolat S215 yang teridentifikasi Bacillus pseudomycoides. Identifikasi bakteri menggunakan uji sequencing $16 \mathrm{~S}$
rDNA cenderung manghasilkan kemiripan (ID) yang lebih tinggi dibandingkan uji secara biokimia. Spesiesspesies penghasil alginat lyase yang berhasil diisolasi dari rumput laut Sargassum sp. ini merupakan galur baru dari spesies yang sudah teridentifikasi sebelumnya dan tersimpan datanya dalam Genbank, karena tidak adanya homologi yang 100\%.

\section{SARAN}

Penelitian lanjutan untuk melihat karakteristik alginat lyase, potensi aplikasi bakteri maupun alginat lyase yang dihasilkan perlu dilanjutkan mengingat informasi mengenai karakteristik dan aplikasi alginat lyase maupun bakteri penghasilnya selama ini masih terbatas, khususnya untuk bakteri asal perairan Indonesia.

\section{DAFTAR PUSTAKA}

Anonymous. (2015). Gram-positive vs Gram-negative bacteria. Retrieved from http://www.diffen.com/ differenceGram-negative_Bacteria_vs_Grampositive_Bacteria\# Pathogenesis_in_human.

Bosshard, P.P., Zbinden, R., Abels, S., Böddinghaus, B., Altwegg, M., \& Böttger, EC. (2006). 16S rRNA gene sequencing versus the API $20 \mathrm{NE}$ system and the VITEK 2 ID-GNB card for identification of nonfermenting Gram-negative bacteria in the clinical laboratory. Journal Clinical Microbiology, 44(4), 13591366.

Gacesa, P. (1992). Enzymatic degradation of alginates. International Journal of Biochemistry, 24, 545-552.

Gibson, G.R. \& Roberfroid, M.B. (1995). Dietary modulation of the human colonic microbiota introducing concept of prebiotics. The Journal of Nutrition. 125, 1401-1412.

Guo, W., Wang,Y., Song, C., Yang, C., Li, Q., Li,B., Su, W., Sun, X., Song, D., Yang, X., \& Wang, S. (2011). Complete genome of Pseudomonas mendocina NK01, which synthesizes medium-chain-length polyhydroxyalkanoates and alginate oligosaccharides. Journal Bacteriology, p. 3413-3414.

Iwamoto, M., Kurachi, M., Nakashima, T., Kim, D., Yamaguchi, K., Oda, T., Iwamoto, Y., \& Muramatsu T. (2005). Structure-activity relationship of alginate oligosaccharides in the induction of cytokine production from RAW264.7 cells. FEBS Letter, 579, 4423-4429.

Kawamoto, H., Horibe, A., Miki, Y., Kimura, T., Tanaka, K., Nakagawa, T., Kawamukai, M., \& Matsuda H. (2006). Cloning and sequencing analysis of alginate lyase genes from the marine bacterium Vibrio sp. $\mathrm{O} 2$. Marine Biotechnology, 8, 481-490.

Khan, Z.H., Khan, M.A., Aftab, M., Idrees, M., \& Naeem, M. (2011). Influence of alginate oligosaccharides on growth, yield and alkaloid production of opium poppy 
(Papaver somniferum L.). Biotechnology Letters, 22, 931-936.

Khan, J.A. (2011). Biodegradation of azo dye by moderately halotolerant Bacillus megaterium and study of enzyme azoreductase involved. Advanced Biotechnology. 10, 21-27.

Kim, D.E., Lee, E.Y., \& Kim, H.S. (2009). Cloning and characterization of alginate lyase from a marine bacterium Streptomyces sp. ALG-5. Marine Biotechnology. 11, 10-16.

Lee, S., Choi, S.H., Lee, E.Y., \& Kim, H.S. (2012). Molecular cloning, purification, and characterization of a novel polyMG-specific alginate lyase responsible for alginate MG block degradation in Stenotrophomas maltophilia $\mathrm{KJ}-2$. Applied Microbiology and Biotechnology. 95(6), 1643-1653.

Li, J.W., Dong, S., Song, J., Li, CB., Chen, XL., Xie, BB., \& Yang, Y.Z. (2011a). Purification and characterization of a bifunctional alginate lyase from Pseudoalteromonas sp. SM0524. Marine Drugs. 9 109-123.

Li, L., Jiang, X., Guan, H., Wang, P., \& Guo, H. (2011b). Three alginate lyases from marine bacterium Pseudomonas fluorescens HZJ216: Purification and characterization. Applied Biochemistry Biotechnology. 164, 305-317.

Lishuxin, H., Jungang, Z., Qiang, P., Hong, L., \& Yuguang, D. (2013). Characterization of a new alginate lyase from newly isolated Flavobacterium sp. S20. Journal of Industrial Microbiology \& Biotechnology. 40(1): 113-122.

Matsushima, R., Danno, H., Uchida, M., Ishihara, K., Suzuki, T., Kaneniwa, M., Ohtsubo, Y., Nagata, Y., \&
Tsuda, M. (2010). Analysis of extracellular alginate lyase and its gene from a marine bacterial strain, Pseudoalteromonas atlantica AR06. Journal of Applied Microbiol Biotechnol, 86, 567-576.

Nakagawa, A., Ozaki, T., Chubachi, K., Hosoyama, T., \& Okubo, T. (1998). An effective method for isolating alginate lyase-producing Bacillus sp. ATB-1015 strain and purification and characterization of lyase. Journal Applied Microbiology, 84, 328-335.

Subaryono, Peranginangin, R, Suhartono, M.T., \& Zakaria, FR. (2013). Alginate lyases: Sources, mechanism of activity and potencial application. Squalen Bulletin of Marine \& Fisheries Postharvest \& Biotechnology, 8(3), 105-116.

Trivedi, P.C., Pandey, S., \& Bhadauria, S. (2010). Text Book of Microbiology. Aaviskhar Publisher. 457 p.

Todar, K. (2015). Todar's online textbook of bacteriology. Retrieved from http://www. Textbookofbacteriology.net /Bacillus_3.html.

Villareal-Gomez, L.J., Soria-Mercado, I.E., Guerra-Rivas, G., \& Ayala-Sáncez, E. (2010). Antibacterial and anticancer activity of seaweeds and bacteria associated with their surface. Revista de Biologia Marina y Oceanografia, 45(2), 267-275.

Wong, T.Y., Preston, L.A., \& Shiller, N.L. (2000). Alginate lyase: review of major sources and enzyme characteristics, structure-function analysis, biological roles, and applications. Annual Review of Microbiology, 54, 289-340.

Xiao, L., Han, F., Yang, Z., Xin-zhi, L., \& Wen-gong, Y. (2006). A novel alginate lyase with high activity on acetylated alginate of Pseudomonas aeruginosa FRD1 from Pseudomonas sp. QD03. World Journal of Microbiology \& Biotechnology, 22, 81-88. 